\title{
ПРОКЛИНАННЯ ЯК РИТУАЛ І ФЕНОМЕН \\ МІФОПОЕТИКИ ЗАЧАРОВАНОЇ ДЕСНИ \\ ОЛЕКСАНДРА ДОВЖЕНКА
}

\author{
ІРИНА ЗЕЛЕНЕНЬКА \\ Вінницький державний педагогічний університет ім. Михайла Коцюбинського, Вінниця - \\ Україна \\ selenenka@ukr.net; ORCID: 0000-0002-3031-775X
}

\section{ВІКТОРІЯ ТКАЧЕНКО}

Вінницький державний педагогічний університет ім. Михайла Коцюбинського, Вінниця Україна

flyform@ukr.net; ORCID: 0000-0003-0492-3817

\section{KLĄTWA JAKO RYTUAŁ I FENOMEN MITOPOETYKI ZACZAROWANEJ DESNY OŁEKSANDRA DOWŻENKI}

\author{
IRYNA ZEŁENEŃKA, WIKTORIA TKACZENKO \\ Państwowy Uniwersytet Pedagogiczny im. Mychajła Kociubynskiego w Winnicy, Winnica - \\ Ukraina
}

STRESZCZENIE. Artykuł został poświęcony klątwom jako elementom mitopoetyki rozpatrywanym na przykładzie powieści filmowej Ołeksandra Dowżenki z przeważającą narracją liryczną pt. Zaczarowana Desna. Autorki podejmują próbę odczytywania figur folkloryzowania (liryzowania) gatunku powieści filmowej za pomocą bogatej synonimii (synonimów kontekstowych), rozbudowanej charakterystyki bohaterów z porównaniami, a także okazjonalnych wypowiedzi w postaci przekleństw. Wszystkie aspekty koloryzacji językowej kondensują wielokulturową przestrzeń tekstu, wielowymiarowość jego poetyki. Dlatego jedną z najbardziej charakterystycznych cech systemu stylistycznego Ołeksandra Dowżenki jest synteza mitów przedchrześcijańskich i chrześcijańskich oraz przedwojennej rzeczywistości, co dobrze ilustruje bogata, wyimaginowana historia małego chłopca i dojrzałego artysty (koncept dualności).

Słowa kluczowe: mitopoetyka, klątwa, impresja, powieść filmowa, narracja liryczna, symbol, folklor 


\title{
CURSES AS A RITUAL AND THE PHENOMENON OF THE MYTHS OF ENCHANTED DESNA BY OLEXANDR DOVZHENKO
}

\author{
IRYNA ZELENENKA, VICTORIA TKACHENKO \\ Vinnytsia Mykhailo Kotsiubynskyi State Pedagogical University, Vinnytsia - Ukraine
}

\begin{abstract}
This article deals with the problem of curses and mythologically poetic stylistics with the example of O. Dovzhenkos' film "The Enchanted Desna". It is a typical lyrical story. This work is the author's attempt to folklorize (lyricize) the genre of cinema through rich synonymy (contextual synonyms), versatile characteristics with comparisons, and occasional expressions (lyrics, curses). All aspects of linguistic colorization of the text constitute the multicultural space of the text, and the multidimensional nature of the poetics of the work. Therefore, one of the very characteristic features of Oleksandr Dovzhenko's stylistic system is the synthesis of pre-Christian and Christian myths and pre-war reality. This is well illustrated by the rich, synonymous story of a small boy and mature artist (the concept of duality). All this brings the style of Dovzhenko's new romance to the style of the impressionist Mikhail Kotsubinsky (in this context, we recall the "Apple Flower").
\end{abstract}

Keywords: mythologicaly poetic, curse, impression, film story, narrative, folklore

$\mathrm{P}$ омантичне світосприйняття й фольклоризація оповіді, імпресіоністичні мазки, глибокий психологізм у творенні образів, персонажів - це те, що було властивим мистецькій палітрі покоління предтеч шістдесятників (зокрема, спадщині Юрія Яновського, Михайла Стельмаха, Олеся Гончара, Григорія Тютюнника), вихованих на кращих зразках раннього українського модернізму й ситуативно солідарних із соцреалістичною практикою. Зосібна, у цьому контексті можна позиціонувати твори на межі літератури й кіномистецтва, що постали з-під пера геніального Олександра Довженка.

У кіноповісті Зачарована Десна, що за багатьма жанровими ознаками більше нагадує ліричну повість, поєдналися такі стильові константи романтичного типу письма: ліризм, емоційність та імпресивність оповіді; гедонізм, катарсизація „на берегах Десни”, де відбувається левова частка подій; світоглядність та ейдична споглядальність покрізь призму „,ерця”; концентрація й переплетення просторових і часових континуумів; поєднання описів-мазків та художньої деталі.

Аналіз актуальних наукових досліджень і публікацій. Намагання фахово поєднати різножанрові мистецькі форми вплинуло на інтенсифікацію естетичного потенціалу стильової манери Олександра Довженка як повістяра та сценариста, про що писали В. Дончик [1994], I. Кошелівець [1980], Н. Медвідь [1998], М. Царинник [1973]. в українському постколоніальному, та 
й у сучасному українському європейському літературознавстві перманентно досліджено сюжетні лінії, фабульність, образи персонажів, психоісторичну концепцію двох Довженків (малого Сашка та зрілого майстра), що є аналогом і відгомоном модерного мислення в Портреті Доріана Грея Оскара Вайльда, у Маленькому приниі Антуана де Сент-Екзюпері, дістає продовження в імпресії дисидентів [Зелененька 2008: 7-8]; вивчено також і багатющу контекстуальну синонімію та психологічні регістри образів [Медвідь 1998: 85-86]. Але функціонування прокльонів як експресії ритуалізації [Кагаров 1928: 26] описано лише побіжно, а тому становить для нас особливий інтерес, $є$ актуальним, своєчасним. Отже, мета статті полягає в аналізі окремих ритуальних формул (прокльонів) як поліекспресивного волевиявлення й навіть ініціації, що колоризовані в Довженковій кіноповісті (дозволимо собі визначення - $i$ ноліроповісті) Зачарована Десна.

Творчості Олександра Довженка властива система символічного відображення світу: своєрідною моделлю світобудови виступають у кіноповісті $3 a-$ чарована Десна дерева, городина, обожнені ріка й сонце у творі широко представлені індивідуально-авторські символи, що транслюють імпресіоністичну якість; усе це $\epsilon$ позиціонуванням міфопоетики. Найцікавішими елементами фольклору, що колоризували мову й міфопоетику твору, посприяли розширенню експресивного поля тексту, є лайка й прокльони. Усі акти (ритуали) проклинання (вчені виокремили прокльони з лайки завдяки їхній фольклорній трансляції й метафоричності) як найпотужніші експресеми зосереджені, що типово для жанру повісті, у тій іiі функціональній частині, де Олександр Довженко дбайливо, ностальгійно, у розлогих ліричних ретроспекціях, у метких дотепах і в локальних філософських роздумах описує свою велику сім'ю, працьовиту родину й дитинство на ще не забруднених берегах Десни.

Потоком, ніби нанизані, як намисто, постають у повісті легенди про добро і зло, про „дівицю” Десну, реалістичні деталі життя й по-бароковому пишно виписана природа над рікою; приказки та прислів'я, українська пісня, дохристиянські й християнські міфи, комічні побутові сцени; у творі деталізовані окремі народні й родинні звичаї. Велемовна експресивна оповідь, що супроводжується колористичними мазками, кореляцією синонімів, прийомами бурлеску, зумовлена романтичним світобаченням Олександра Довженка й ностальгійною потребою України як батьківщини: „А малини - красної, білої! а вишень, а груш солодких було як наїсися - цілий день живіт, як бубон” [Довженко 1995: 17].

Яскрава предметна чуттєвість образів-персонажів загострюється під впливом контрастування позитивних (дитинство, праця, Десна) і негативних (війна, голодне життя, руйновища) спогадів письменника, у зв'язку з чим романтичний пафос заміщується реалістичним. Поліемоційність найчастіше досягається в результаті зіткнення християнського (картина „Страшного суду”, віра 
в Бога, віра в благословення), так би мовити, навколохристиянського (трактування картини матір'ю Сашка), дохристиянського (віра у природу, сакралізація Десни, віра у згубну силу проклинання, страх перед прокльонами):

Батькові чорти наливали в рот гарячу смолу, щоби не пив горілки і не бив матері. Баба лизала гарячу сковороду за довгий язик і за те, що була велика чаклунка. Діда [...] тримав у руках сам диявол за те, що він чорнокнижник $\mathrm{i}$, читаючи по неділях Псалтир, заклинав... [Довженко 1995: 23-24].

Згадаємо тут також образи-символи батька й діда, які є архетипними: „, нас був дід дуже схожий на Бога...” [Довженко 1995: 17]; „Образ святого Миколая також був схожий на діда...” [Довженко 1995: 17]; „Святий Феодосій більше скидався на батька...” [Довженко 1995: 17], але при цьому вони могли прикинути гостре слівце: „- Туди йому й дорога, ідолу. Хоч людей не буде лякати, - сказав наш батько й плюнув. - Не старець, чорти б його забрали, а наче дуб, розбитий громом...” [ Довженко 1995: 27]. Із чоловіків у родині найбільше це полюбляв дід: „- Та йди ти під три чорти! Не дратуй мене, крутишся тут, нечистий вас носить! - розгнівався дід...” [Довженко 1995: 19].

Окремішньо, цілком автономно постає колоритна, найбільш дбайливо виписана (про що свідчать контекстуальні синоніми), прабаба, яку в повісті не раз названо бабою (маємо тут повторювану трансляцію літоти); проклинання стає рисою характеру літньої жінки-трудівниці:

Їй можна було по три дні не давати їсти. Але без прокльонів вона не могла прожити й дня. Вони були ії духовною їжею. Вони лились з її вуст потоком, як вірші з натхненного поета, 3 найменшого приводу. Це була творчість її палкої, темної, престарілої душі... [Довженко 1995: 18].

Лайка (лайливі, татуйовані слова) та прокльони, що мають спільне походження й подібне енергетичне плюсування та застосування в негативній емоційно-оцінній ситуації, $\epsilon$, по суті, породженням агресії. Але прокльони не $\epsilon$ ініціативною агресією, лише відповіддю на репліку чи дію, больовою реакцією на ганебний чи підлий вчинок, що вражатиме кривдника енергетично. в основі виникнення акту проклинання як побутового лихослів'я чи ритуалізації знаходиться межова негативна експресія, котру людині складно пережити. Тому прокльони кваліфікують як утилітарно-сакральні тексти, що належать до оказіонально-обрядового фольклору [Гунчик 2005: 3-4].

Спостерігаючи за авторською концепцією творення персонажа за репліками, вкладеними автором в уста прабаби, робимо висновок про те, що проклинання було для літньої жінки радше щоденною емоційною нормою та необхідністю. Водночас це виявляється ганджем і способом словесної уніфікації власних переживань, втечею від спогадів і наслідком морального, емоційного перенапруження, зумовленого важкими буднями в українському селі I поло- 
вини XX століття (зміна режимів, революція, війни, репресії, колективізація), а відтак, ритуалізацією поведінки персонажа.

Експлікативні та апелятивні прокльони [Гунчик 2005: 5-6], якими багата повість, зокрема мовлення прабаби, вирізняються насиченістю порівняннями, епітетами; місткі змістовно й словесно, ступеневі, про що свідчить їхня синтаксична будова. Можемо поділити їх на кілька груп:

1) прокльони-звернення до Бога та інших святих з метою покарання винуватця: „Мати Божа, Цариця Небесна! Як не дає він мені спокою, не дай йому ні на тому світі, ні на сьому !.." [Довженко 1995: 16];

2) прокльони, в яких згадувалася демонологія: „Га, не здохнеш ти! Киш, нечиста сило!..” [Довженко 1995: 40];

3) прокльони-апеляції до природних стихій, явищ, фауни: „Га! Щоб бодай вам добра не було, вовки б вас загризли...” [Довженко 1995: 27];

4) прокльони з насланням хвороб і нещасть: „Куди ти тютюн ламаєш, бодай тобі руки і ноги поламало! а бодай би ти не виліз з того тютюну до другого пришестя. Щоб ти зів'яв був, невігласе, як ота морквочка зів'яла від тих шибенних рук!.. " [Довженко 1995: 11].

Характеристика адресатів проклинання передавалася, що ілюструють цитовані приклади, вельми стисло; найчастіше у займенниках непрямих відмінків - родового, давального, рідше - називного. Завдяки цьому прийомові автор наслідує народну мову, перенасичену займенниками, зокрема, особовими.

Попрохавши про щось жінку-берегиню, спершу потрібно було вислухати прокльони, а потім отримати бажане. Для прикладу, дід, який любив лежати на погребні, попросивши узвару, найперше отримав у відповідь три автономних акти галасливого проклинання зі ступеневим насиланням хвороб (пранuุi- народна назва венеричної хвороби) і градаційно - смерті: „Га? Це ти тут лежиш, бодай би ти не встав!.. ” [Довженко 1995: 12]; „Зараз принесу, бодай тебе пранці з'їли, щоб ти їв і не наїдався, щоб тебе розірвало, щоб ти луснув, як був маленьким!.. " [Довженко 1995: 13]. Окремі з прокльонів, адресованих малому Сашкові, можна охарактеризувати як фатально-прогностичні: „Покарайте його, святі, голубоньки, і ти, Мати Божа, такою роботою, щоб не знав він ні сну, ні відпочинку, і пошліть йому, благаю вас, такого начальника...' [Довженко 1995: 17]. Проклинаючи, лаючись, жінка намагалася самочинно утвердити свій авторитет у всіх справах родини, котра вже не звертала уваги на надмірну вербалізацію негативних емоцій з уст найстаршої жінки в хаті. Саме цією латентною компромісністю й відрізняється побут родини Довженків, змальований у Зачарованій Десні, від побуту родини Кайдашів у власне реалістичній Кайдамевій сім'ї Івана Нечуя-Левицького.

У зображенні прабаби та іiі стосунків з автобіографічним героєм Зачарованої Десни підкреслено елемент індивідуальної творчості, яка реалізується саме через прокльони. Прабаба, твердить автор, мала надзвичайно багате 
образне мислення, адже прокльони вигадувала сама, використовуючи типові фольклорні формули, домислюючи в їхньому ключі нові оказіональні семи, насичуючи їх символами, номенами явищ дійсності, збагачуючи процесуальністю, навіть певною подієвістю, Повістяр влучно доносить це до реципієнта через препозитивне порівняння:

Як дід Семен любив сонце, так само баба любила прокльони. Вона проклинала все, що попадалось їй на очі, - свиней, курей, поросят, щоб не скугикали, Пірата, щоб не гавкав і не гидив, дітей і сусідів. Кота вона проклинала щодня по два-три рази, так що він згодом був якось захворів, аж поки не здох десь у тютюні... [Довженко 1995: 12].

Зображене в повісті Олександра Довженка проклинання, характерне для мовлення українців першої половини ХХ століття, має різну практичну мотивацію. Воно викликане не лише природними психологічними реакціями персонажів, як-от емоціями заздрості, гніву, страху, люті, відчаю. Частіше прокльони сприймаються як жарт і дотеп, зрідка - як незворотнє пророцтво. Загалом їм не властиві рецидиви вульгарності (пригадаймо для зіставлення мовлення Рахіри та Маріки Федорчук у повісті Земля Ольги Кобилянської). Олександр Довженко не засуджує героїню, а пояснює її словесний вибір, характеризуючи проклинання як соціально мотивовану недобру звичку.

Малий Сашко боявся прабаби, бо за перманентним проклинанням бачив iii чаклунство [Довженко 1995: 12], і заспокоївся лише тоді, коли жінка померла: „Закрилися всевидячі вічки, ущухла народна пристрасна ії творчість, і всі їі прокляття немовби вилетіли 3 хати разом 3 душею. Ой, коли б хто знав, яка то радість, коли вмирають прабаби, особливо зимою, в стареньких хатах" [Довженко 1995: 25]. Оцю саркастично описану контроверсійну рису характеру, схильність до побожності й до проклять одночасно, мають чи не всі члени родини Олександра Довженка, однак на прикладі розповіді Сашка вона $€$ найпомітнішою.

Через психологічний стан пережитих страждань і втрат у життях баби, діда, матері й батька, котрі втратили „синів-соловейків”, О. Довженко майстерно розкриває світлий сум і гіркаву радість тих людей, які колись жили на берегах Десни, їхній потяг до велемовності й до краси, балансування між низьким-профанним і урочистим, немічність серед зла й намагання за будьяку ціну утвердитися через працю й повагу до природи. Усе це наближає манеру неоромантика Олександра Довженка до манери імпресіоніста Михайла Коцюбинського: у цьому контексті пригадаймо етюдно-новелістичний твір Цвіт яблуні, де подібні мотиви розгорнуто в дусі імпресіонізму.

Поєднання міфологізованих вражень від природи, мови персонажів (прокльонів зокрема), життя й дитинства над Десною нагадують яскраві мазки в експресіонізмі. Отже, неоромантичний й експресіоністичний типи світосприйняття Олександра Довженка виявилися у вмінні показати буденне й ре- 
альне в героїчних, піднесених, бурлескних, міфологічних тонах, мислити картинно й гіперболічно водночас, у межах властивих для кіно масштабних художніх узагальнень. Саме ця особливість світогляду мистця уможливлює розкриття внутрішнього світу героїв у взаємодії з природними законами навколишньої дійсності.

Відтак, однією з найхарактерніших ознак стильової системи Олександра Довженка є синтез дохристиянських та християнських міфів і довоєнної реальності, що добре ілюструє багата на синоніміку розповідь малого Сашка. У ній майстерно передано колорит емоційних переживань хлопчика, викликаних прокльонами прабаби або спогадами про пса Пірата, котрий пропав нібито через ті прокльони.

Отже, Зачарована Десна Олександра Довженка, що за більшістю ознак нагадує ліричну повість, $є$ авторською спробою фольклоризації (ліризації) жанру кіноповісті за допомогою багатої синонімії (контекстуальних синонімів), розлогих характеристик персонажів із порівняннями, а також оказіональних висловлювань (лайки, прокльонів). Усі вказані аспекти мовної колоризації тексту автор успішно застосовує, що переконливо доводить наукова розвідка, задля ущільнення текстуального полікультурного простору, згущення багатовимірності поетики твору. Прийоми фольклору успішно використовували письменники-реалісти Іван Нечуй-Левицький та Іван Франко, модерністки Леся Українка й Ольга Кобилянська, проте Олександр Довженко надає їм особливої виразності: не лише удоступнює, а й робить максимально ресурсними на рівні поетики жанру, сюжету й образів-персонажів.

\section{Список використаної літератури}

Гончарова Н., Проблема міфологічного символізму в контексті культури, автореферат дисертації... канд. філолог. наук, Київ 1998.

Гунчик I., Український оказіонально-обрядовий фольклор: структурно-функиіональний аспект, автореферат дисертації... канд. філолог. наук, Львів 2005.

Зелененька I., „Чиї ие ілюзї̈ стенають плечима, якого народу...”: Тарас Мельничук $i$ літературний проиес 60-90-х років в Україні, Вінниця: Едельвейс і К, 2008.

Дончик В.Г., Олександр Довженко, [в:] „Історія української літератури ХХ ст.: у 2 кн., кн. 2: Друга половина ХХ ст.”, підручник, за ред. В.Г. Дончика, Київ: Либідь, 1994, с. 218-227.

Кагаров Є., Форми та елементи народної обрядовості: Первісне громадянство та його пережитки на Україні, вип. 1, Київ, 1928, с. 25-31.

Кошелівець І., Олександр Довженко. Спроба творчої біографії, Мюнхен: Сучасність, 1980. Літературознавчий словник-довідник, за ред. Р. Гром'яка та ін., Київ: Академія, 1997.

Медвідь Н., Засоби психологічного аналізу у творчості О. Довженка воєнного періоду, „Наукові записки Харківського педуніверситету імені Г. С. Сковороди”, серія: Літературознавство, вип. 7 (18), Харків 1998, с. 85-90. 
Медвідь Н., Національна своєрідність психологізму О. Довженка, „Дивослово”, 1999, № 9, c. 53-55.

Теорія літератури, підручник, за наук. ред. О. Галича, Київ: Либідь 2008.

Украӥнська література. 11 кл., підручник для загальноосвітніх шкіл, за загал. ред. Р. Мовчан, Київ-Ірпінь: ВТФ „Перун”, 2001.

Царинник М., Плянетне видиво: міфотворче світовідчування Олександра Довженка, „Сучасність”, 1973, ч. 10.

\section{Spysok vykorysranoi literatury \\ [References]}

Honcharova N., Problema mifolohichnoho symvolizmu v konteksti kultury [The problem of mythological symbolism in the context of culture], avtoreferat dysertatsii kand. filoloh. nauk, Kyiv, 1998.

Hunchyk I., Ukrainskyi okazionalno-obriadovyi folklor: strukturno-funktsionalnyi aspekt [Ukrainian occasional and ceremonial folklore: structural and functional aspect], avtoreferat kandydata filolohichnykh nauk, Lviv, 2005.

Zelenenka I., „Chyi tse iliuzii stenaiut plechyma, yakoho narodu...”: Taras Melnychuk i literaturnyi protses 60-90-kh rokiv v Ukraini ["Whose illusions shrug their shoulders, what kind of people...": Taras Melnychuk and the literary process of the 60-90s in Ukraine], Vinnytsia: Edelveis i K., 2008.

Donchyk V.H., Oleksandr Dovzhenko [Oleksandr Dovzhenko], [v:] Istoriia ukrainskoi literatury $X X$ st. [History of Ukrainian literature of the twentieth century], u $2 \mathrm{kn} ., \mathrm{kn} .2$ : Druha polovyna XX st. Pidruchnyk, za red. V.H. Donchyka. Kyiv: Lybid, 1994, s. 218-227.

Kaharov Ye., Formy ta elementy narodnoi obriadovosti: Pervisne hromadianstvo ta yoho perezhytky na Ukraini [Forms and elements of folk rituals: Primitive citizenship and its remnants in Ukraine], vyp. 1, Kyiv 1928, s. 25-31.

Koshelivets I., Oleksandr Dovzhenko. Sproba tvorchoi biohrafii [Olexandr Dovzhenko. An attempt at a creative biography], Miunkhen: Suchasnist, 1980.

Literaturoznavchyi slovnyk-dovidnyk [Literary dictionary-reference book], za red. R. Hromiaka ta in., Kyiv: Akademiia, 1997.

Medvid N., Zasoby psykholohichnoho analizu u tvorchosti O. Dovzhenka voiennoho periodu [Means of psychological analysis in the work of O. Dovzhenko of the war period], „Naukovi zapysky Kharkivskoho peduniversytetu imeni H.S. Skovorody”, ceriia: Literaturoznavstvo, vypusk 7 (18), Kharkiv, 1998, s. 85-90.

Medvid N., Natsionalna svoieridnist psykholohizmu O. Dovzhenka [National originality of Dovzhenko's psychologism], „Dyvoslovo”, 1999, no 9, s. 53-55.

Teoriia literatury [Theory of literature], pidruchnyk, za nauk. red. O. Halycha, Kyiv: Lybid, 2008. Ukrainska literatura [Ukrainian literature], 11 kl. Pidruchnyk dlia zahalnoosvitnikh shkil, za zahal. red. R. Movchan, Kyiv-Irpin: VTF „Perun”, 2001.

Tsarynnyk M., Plianetne vydyvo: mifotvorche svitovidchuvannia Oleksandra Dovzhenka [Planetary vision: myth-making worldview of Oleksandr Dovzhenko], „Suchasnist”, 1973, ch. 10. 


\section{Список використаних джерел}

Довженко О., Зачарована Десна. Україна в огні. Щоденник, передм. М. Жулинського, Київ: Веселка, 1995.

\section{Spysok vykorystanykh dzherel [References]}

Dovzhenko O., Zacharovana Desna. Ukraina v ohni. Shchodennyk [Enchanted Desna. Ukraine on fire. Diary], peredm. M. Zhulynskoho, Kyiv: Veselka, 1995. 
